\title{
Evaluation of Elite Accessions of Rice for Morphological and Nutritional Traits
}

\author{
Saurabh Pandey* , D. Dayal Doss and H.E. Shashidhar \\ Department of Plant Biotechnology, University of Agricultural Sciences Bangalore-65, \\ Karnataka, India \\ *Corresponding author
}

\section{A B S T R A C T}

\begin{tabular}{|l|}
\hline Ke y w or d s \\
Rice, Zinc, Iron \\
content, Mean \\
performance, Yield \\
\hline Article Info \\
\hline $\begin{array}{l}\text { Accepted: } \\
\text { 28 January } 2018 \\
\text { Available Online: } \\
\text { 10 February } 2018\end{array}$ \\
\hline
\end{tabular}

\section{Introduction}

Rice (Oryza sativa L.) is a "Global Grain" cultivated widely across the world feeding millions of mankind. It is grown over 160 million hectares and providing 20 per cent daily calories for half of the world's population. More than 3.5 billion people are depending upon rice as a staple food and one fifth of the world population depend on rice cultivation for their livelihoods. Asia produces and consumes about 90 per cent of the world's rice (www.sustainablerice.org). It has been reported that rice significantly lack some of the micronutrients such as $\mathrm{Fe}, \mathrm{Zn}, \mathrm{Ca}, \mathrm{Mg}, \mathrm{Cu}$, $\mathrm{I}$ and Se etc., which are important for human
The fourteen genotypes selected were grown during Kharif-2014 at in order to evaluate the performance of fourteen elite accessions of rice for yield and its component traits. The present experiment was laid under randomized complete block design with three replications at field under aerobic rice/biotechnology rice research laboratory, Department of Plant Biotechnology, University of Agricultural Sciences, GKVK campus, Bangalore, India during Kharif-2014. Analysis of variance for all morphological traits shown that mean sum of squares due to genotypes was highly significant for all characters. Among all AM-1 variety. Also high iron content of brown rice was found in BR-2655 while Moroberekkan variety showed minimum polishing loss of iron. Meanwhile Moroberekkan variety had maximum zinc content for both brown and white rice which proves it's suitability as bio fortified consumption grain. 
productivity, reduced mental capacity, stunting, blindness, increased child mortality, and elevated morbidity and mortality in general (Baishya et al., 2015).Considering the above factors, this study has been undertaken with the aim of comparison of quantification of Iron and Zinc in the brown, white, and cooked rice in elite accessions along with their mean performance with agronomic traits.

\section{Materials and Methods}

\section{Studies of morphological traits}

The present experiment was conducted at aerobic rice laboratory, Department of Plant Biotechnology, University of Agricultural Sciences, GKVK campus, Bangalore, India during Kharif-2014in order to evaluate the performance of fourteen genotypes of rice for various yield and its component traits. The genotypes were sown in rows spacedat $30 \mathrm{~cm}$ apart with intra-row spacing of $15 \mathrm{cmwith}$ three replications each.

The recommended dose of fertilizer i.e. nitrogen $100 \mathrm{Kg}$, phosphorus $50 \mathrm{Kg}$ and potassium $50 \mathrm{Kg}$ along with 5 tone of FYM per hectare was applied. $\mathrm{N}$ was applied in the form of urea at basal, 30 and 60 DAS @ 50\%, $25 \%$ and $25 \%$ respectively. $\mathrm{P}$ was provided through single super phosphate $\left(\begin{array}{lll}16 & \% & \mathrm{P}_{2} \mathrm{O}_{5}\end{array}\right)$ and $\mathrm{K}$ as Murite of potash $\left(\begin{array}{lll}60 & \% & \mathrm{~K}_{2} \mathrm{O}\end{array}\right)$. Irrigation was done once in five days. All necessary measures were taken to control pest and disease infestation. Study of physicochemical properties of soil at the experimental site showed the presence of0.74 ppm Zn (estimated using DTPA, diethylene triaminepenta acetic acid extractable method), a pH of 6.1 and $7.4 \mathrm{~g} \mathrm{~kg}^{-1}$ of organic carbon. The study on analysis of variance and mean performance of genotypes was carried out for morphological traits viz., plant height, total number of tillers, number of productive tillers, panicle length, percentage spikelet fertility, days to first flowering, hundred grain weight, days to $50 \%$ flowering, days to maturity and shoot dry weight.

\section{Estimation $\mathrm{Zn}$ and $\mathrm{Fe}$ content in brown, white and cooked rice}

The dehusked $5 \mathrm{~g}$ samples (brown rice) of the fourteen genotypes in three replications were subjected to X-rays and the content was recorded in $\mathrm{mg} / \mathrm{kg}$ using florescence (XRF) (OXFORD Instruments X-Supreme 8000, Nicholas et al., 2012) at ICRISAT, Hyderabad, Andhra Pradesh. Measurement conditions were followed as recommended by the manufacture for analysis of $\mathrm{Zn}$ and $\mathrm{Fe}$ in a cellulose matrix. Analysis time for each sample was $186 \mathrm{~s}$, which included $60 \mathrm{~s}$ acquisition time for the separate $\mathrm{Zn}$ and $\mathrm{Fe}$ conditions as well as $66 \mathrm{~s}$ 'dead time' during which the XRF establishes each measurement condition.

Scans was conducted in sample cups assembled from $21 \mathrm{~mm}$ diameter all cups combined with polypropylene inner cups sealed at one end with $4 \mu \mathrm{m}$ Poly-4 XRF sample film. Calibration of instrument was done using known ICP-OES values of high, low zinc and iron containing genotypes (Gande et al., 2014).

$\mathrm{Zn}$ and $\mathrm{Fe}$ content were estimated from the white rice which was collected individually from each genotypes using $10 \mathrm{~g}$ brown rice sample and polished by nonferrous miller (Mini Lab Rice Polisher Model K-710, Krishi International) DRR, Hyderabad. Machine was cleaned with brush internally and externally after every turn of polishing. XRF readings were taken for all the white rice samples at ICRISAT, Hyderabad. $\mathrm{Zn}$ and Fe content in cooked rice (mg kg-1) $\mathrm{Zn}$ and Fe content was estimated from the cooked rice samples of all genotypes by XRF method in MSSRF, Chennai. 


\section{Observations of cooking parameters}

Cooking parameters which were studied for the all genotypes are kernel length before cooking (mm), kernel length after cooking $(\mathrm{mm})$, water uptake before cooking (ml), water uptake after cooking (ml) and volume expansion and elongation ratio. For measuring the kernel length before and after cooking, average of 10 grains was taken. Water uptake for all genotypes before cooking was measured by adding $5 \mathrm{~g}$ of samples in $15 \mathrm{ml}$ distilled water for 10 minutes. Water uptake after cooking was measured by dipping the cooked samples in $50 \mathrm{ml}$ distilled water for 10 minutes. Elongation ratio for the grain was calculated as the ratio of kernel length after cooking and cooking, respectively. Volume expansion was calculated as increase in the volume after cooking (X-50) and before cooking (Y-15).

\section{Results and Discussion}

\section{Analysis of variance}

The phenotypic variation manifested by the genotype has two components namely genotypic and environmental. Analysis of variance of 23 among 23 characters revealed high significant difference among the means of all the genotypes (Table 1) thus indicating considerable scope for selection even for micronutrient distribution in rice grain. This difference can be attributed to variations present in the genotypes as well as the environmental factors.

\section{Mean performance of genotypes for different morphological traits:}

The mean values of different growth and yield parameters with respect to genotypes are presented in table 4. Among the selected genotypes, BR-2655 showed minimum plant height at maturity $(52.33 \mathrm{~cm})$, whereas maximum plant height was observed in AM$65(103.73 \mathrm{~cm})$, with an average of $80.07 \mathrm{~cm}$. Total number of tillers varied from 6.36 (Moroberekkan) to 15.33 (Karthika) with an average of 10.91. Number of productive tillers was observed maximum in genotype karthika (12.56) and minimum in Moroberekkan (4.20) with an average of 8.43 .

The genotype AM-1possessed maximum panicle length of $21.90 \mathrm{~cm}$, whereas minimum panicle length was observed in BR-2655 (16.07) with the average value of $18.78 \mathrm{~cm}$. Percentage spikelet fertility varied from 61.12 (AM-65) to 69.71 (AM-1) with an average of 64.60.Among the selected genotypes, days to first flowering were minimum in Black rice (72days) and maximum in Karthika (122.33 days). Among the selected genotypes, range of variation for days to fifty percent flowering was from 95 (Black rice) to 137 (Karthika) with an average of 111 days. Maturity was attained within minimum number of121.67days in genotype AM-1, whereas Karthika took maximum (148.67 days) time to attain maturity. An average value of 132.02 days was recorded for days to maturity.

Hundred grain weight ranged from 1.20 gram (Radhunipagal) to 2.58 gram (Moroberekkan) with an average values of 1.95gram.Maximum grain yield per plant was obtained in TKM9(30.53 g), whereas it was observed to be minimum in AM-72(4.02 g), with overall mean of $13.73 \mathrm{~g}$.

The magnitude of phenotypic variability is reflected by range and deviation from the mean values. High range was noticed for days to $50 \%$ flowering, total number of tillers, number of productive tillers, plant height, panicle length, days to maturity, shoot dry weight, grain yield per plant. Similar results were obtained by Hemareddy (1993), Dhananjaya et al., (1998), Venkataramana and Hittalmani (1999), and Nagabhushana (2002). 
Table.1 Analysis of variance for morphological characters

\begin{tabular}{|l|l|l|l|l|l|l|l|}
\hline $\begin{array}{l}\text { Source } \\
\text { variation }\end{array}$ & of & DFF & DFPF & NT & NPT & PH & PL \\
\hline $\begin{array}{l}\text { Genotype } \\
\text { Error }\end{array}$ & 13 & $790.10^{* *}$ & $564.10^{* *}$ & $16.56^{* *}$ & $15.21^{* *}$ & $997.43^{* *}$ & $9.33^{* * *}$ \\
\hline CD at 5\% & 26 & 42.55 & 41.96 & 1.81 & 1.01 & 35.17 & 2.03 \\
\hline CD at 1 \% & & 10.95 & 10.87 & 2.04 & 1.69 & 9.95 & 2.39 \\
\hline CV & 14.80 & 14.70 & 2.75 & 2.28 & 13.45 & 3.23 \\
\hline
\end{tabular}

\begin{tabular}{|l|l|l|l|l|l|l|}
\hline Source of variation & df & PSF & DM & SDW & HGW & GY/P \\
\hline Genotype & 13 & $21.49^{* *}$ & $212.13^{* *}$ & $58.74^{* *}$ & $0.43^{* *}$ & $207.87^{* *}$ \\
\hline Error & 26 & 4.42 & 16.08 & 15.02 & 0.07 & 2.47 \\
\hline CD at 5\% & 3.53 & 6.73 & 6.50 & 0.44 & 2.64 \\
\hline CD at 1 \% & & 4.77 & 9.10 & 8.79 & 0.60 & 3.56 \\
\hline CV & 3.26 & 3.04 & 12.10 & 13.51 & 11.45 \\
\hline
\end{tabular}

** Significant at $1 \%$

$\mathrm{PH}=$ Plant height

NT=Total number of tillers

NPT $=$ Number of productive tillers

$\mathrm{PL}=$ Panicle length

SDW=Shoot dry Weight
HGW=Hundred grain weight

$\mathrm{DFF}=$ Days to first flowering

$\mathrm{DFPF}=$ Days for $50 \%$ flowering

$\mathrm{DM}=$ Days to maturity

$\mathrm{PSF}=$ Percentage spikelet fertility

Table.2 Average Zinc and Iron contents $\left(\mathrm{mg} \mathrm{kg}^{-1}\right)$ in different parts of rice grain

\begin{tabular}{|l|l|l|l|l|l|l|}
\hline \multirow{2}{*}{ Genotypes } & \multicolumn{3}{l}{ BROWN RICE } & \multicolumn{2}{l|}{ WHITE RICE } & \multicolumn{2}{l|}{ COOKED RICE } \\
& ZINC & IRON & ZINC & IRON & ZINC & IRON \\
\hline AM 27 & 27.05 & 11.70 & 22.20 & 5.85 & 21.65 & 22.10 \\
\hline AM 65 & 35.05 & 14.35 & 31.55 & 4.00 & 26.90 & 12.75 \\
\hline AM-72 & 33.60 & 12.65 & 32.65 & 4.85 & 29.45 & 14.75 \\
\hline AM-158 & 34.70 & 14.60 & 28.55 & 5.30 & 24.05 & 19.15 \\
\hline Black Rice & 23.35 & 12.20 & 24.20 & 7.50 & 20.80 & 20.30 \\
\hline BI-33 & 23.55 & 14.65 & 23.10 & 14.05 & 22.65 & 10.55 \\
\hline AM-143 & 24.20 & 10.90 & 23.95 & 5.30 & 20.50 & 20.15 \\
\hline AM-1 & 24.05 & 15.40 & 23.75 & 3.75 & 21.45 & 15.90 \\
\hline RadhuniPagol & 27.80 & 17.50 & 21.65 & 11.65 & 18.55 & 31.10 \\
\hline BR-2655 & 25.80 & 21.70 & 23.20 & 5.80 & 18.80 & 23.95 \\
\hline Karthika & 43.00 & 13.40 & 34.20 & 6.15 & 33.20 & 24.45 \\
\hline Subhdra & 25.00 & 17.55 & 18.70 & 2.20 & 15.45 & 6.85 \\
\hline Moroberekkan & 38.80 & 14.90 & 37.45 & 13.85 & 33.5 & 10.5 \\
\hline TKM-9 & 23.85 & 11.00 & 22.10 & 4.75 & 19.35 & 16.90 \\
\hline
\end{tabular}

Table.3 Analysis of variance for cooking characters in elite rice accessions

\begin{tabular}{|l|l|l|l|l|l|l|l|}
\hline $\begin{array}{l}\text { Source of } \\
\text { variation }\end{array}$ & df & KLBC & KLAC & WUBC & WUAC & ER & VE \\
\hline Genotype & 13 & $0.04^{* *}$ & $0.03^{* *}$ & $1.96^{* *}$ & $17.28^{* *}$ & $2.22^{* *}$ & $1.31^{* * *}$ \\
\hline Error & 26 & 0.00 & 0.00 & 0.05 & 0.47 & 0.06 & 0.07 \\
\hline CD at 5\% & 0.02 & 0.03 & 0.39 & 1.15 & 0.43 & 0.46 \\
\hline CD at 1 \% & 0.03 & 0.04 & 0.53 & 1.56 & 0.58 & 0.61 \\
\hline CV & & 6.38 & 2.10 & 6.32 & 5.23 & 6.52 & 7.47 \\
\hline
\end{tabular}

$\mathrm{KLBC}=$ kernel length before cooking

$\mathrm{KLAC}=$ Kernel length after cooking

WUBC $=$ water uptake before cooking

WUAC=water uptake after cooking 
Table.4 Mean performance of different genotypes for yield and its components

\begin{tabular}{|c|c|c|c|c|c|c|c|c|c|c|c|c|c|c|c|}
\hline Genotype & $\begin{array}{l}\text { Plant } \\
\text { height }\end{array}$ & NT & NPT & SDW & $\begin{array}{l}\text { Grain } \\
\text { yld. } \\
\text { Per } \\
\text { plant }\end{array}$ & PL & HGW & DFF & DFPF & DM & PSF & BRF & WRF & BRZ & WRZ \\
\hline AM-27 & 73.20 & 12.67 & 9.67 & 27.16 & 21.11 & 21.65 & 2.37 & 99.00 & 107.67 & 132.67 & 67.72 & 11.70 & 5.85 & 27.05 & 22.20 \\
\hline AM-65 & 103.63 & 9.45 & 6.50 & 38.07 & 10.26 & 19.15 & 2.06 & 107.67 & 124.33 & 138.00 & 64.46 & 14.35 & 4.00 & 35.05 & 31.55 \\
\hline AM-72 & 64.86 & 13.47 & 9.00 & 31.42 & 3.69 & 18.39 & 1.93 & 107.33 & 118.33 & 134.00 & 65.68 & 12.65 & 4.85 & 33.60 & 32.65 \\
\hline AM-158 & 68.40 & 13.93 & 8.13 & 29.64 & 11.84 & 18.54 & 1.91 & 82.00 & 103.67 & 127.33 & 63.20 & 14.60 & 5.30 & 34.70 & 28.55 \\
\hline black rice & 98.80 & 13.73 & 8.40 & 31.10 & 15.35 & 19.92 & 2.18 & 72.00 & 95.00 & 123.33 & 68.77 & 12.20 & 7.50 & 23.35 & 24.20 \\
\hline BI-33 & 97.50 & 12.07 & 7.80 & 31.05 & 14.66 & 19.79 & 1.61 & 84.00 & 102.00 & 125.33 & 68.47 & 14.65 & 14.05 & 23.55 & 23.10 \\
\hline AM-143 & 61.57 & 13.35 & 7.56 & 24.87 & 13.30 & 17.26 & 1.74 & 84.67 & 99.00 & 126.67 & 70.56 & 10.90 & 5.30 & 24.20 & 23.95 \\
\hline$\overline{A M-1}$ & 101.47 & 13.53 & 8.67 & 39.23 & 30.01 & 21.90 & 2.30 & 74.00 & 95.67 & 121.67 & 69.71 & 15.40 & 3.75 & 24.05 & 23.75 \\
\hline RadhuniPagal & 89.20 & 16.18 & 9.73 & 44.23 & 5.35 & 17.23 & 1.20 & 105.00 & 120.00 & 137.33 & 69.85 & 17.50 & 11.65 & 27.80 & 21.65 \\
\hline BR-2655 & 52.33 & 13.71 & 8.40 & 33.72 & 4.34 & 21.47 & 1.54 & 115.33 & 127.67 & 143.33 & 67.60 & 21.70 & 5.80 & 25.80 & 23.20 \\
\hline Karthika & 76.67 & 20.77 & 16.23 & 32.26 & 12.78 & 16.07 & 1.59 & 122.33 & 137.00 & 148.67 & 59.48 & 13.40 & 6.15 & 43.00 & 34.20 \\
\hline Subhdra & 64.07 & 17.53 & 10.57 & 25.16 & 17.94 & 17.33 & 2.26 & 78.67 & 96.00 & 123.33 & 70.62 & 17.55 & 2.20 & 25.00 & 18.70 \\
\hline Moroberekkan & 103.73 & 6.36 & 3.86 & 40.30 & 6.36 & 20.39 & 2.58 & 108.00 & 122.67 & 140.00 & 64.82 & 14.90 & 13.85 & 38.80 & 37.45 \\
\hline TKM-9 & 65.27 & 14.60 & 9.50 & 28.27 & 22.02 & 18.17 & 2.05 & 89.33 & 105.00 & 126.67 & 67.12 & 11.00 & 4.75 & 23.85 & 22.10 \\
\hline Mean & 79.31 & 13.67 & 8.86 & 32.61 & 13.50 & 19.09 & 1.95 & 94.95 & 111.00 & 132.02 & 67.00 & 14.46 & 6.79 & 29.27 & 26.23 \\
\hline S.D & 17.93 & 2.86 & 2.46 & 5.79 & 7.48 & 1.83 & 0.38 & 16.23 & 13.71 & 8.41 & 3.18 & 2.96 & 3.71 & 6.50 & 5.61 \\
\hline C.V & 22.61 & 20.92 & 27.75 & 17.77 & 55.39 & 9.60 & 19.53 & 17.09 & 12.35 & 6.37 & 4.74 & 20.48 & 54.75 & 22.19 & 21.40 \\
\hline \multicolumn{5}{|c|}{$\begin{array}{l}\text { PH=Plant height } \\
\text { NT=Total number of tillers } \\
\text { NPT=Number of productive tillers } \\
\text { PL=Panicle length } \\
\text { SDW=Shoot dry Weight } \\
\text { BRF }=\text { Fe content in brown rice } \\
\text { BRZ }=\text { Zn content in white rice }\end{array}$} & $\begin{array}{l}\text { HG } \\
\text { DFF } \\
\text { DFP } \\
\text { DM } \\
\text { PSF } \\
\text { WR } \\
\text { WR }\end{array}$ & $\begin{array}{l}=\text { Hundr } \\
\text { Days to } \\
=\text { Days } \mathrm{f} \\
\text { Days to } \\
\text { Percent } \\
=\text { Fe con } \\
=\mathrm{Zn} \text { con }\end{array}$ & $\begin{array}{l}\text { grain we } \\
\text { st flowe } \\
50 \% \text { flo } \\
\text { turity } \\
\text { spikele } \\
\text { t in Wh } \\
\text { it in whi }\end{array}$ & $\begin{array}{l}\text { ght } \\
\text { ng } \\
\text { vering } \\
\text { fertility } \\
\text { e rice } \\
\text { rice }\end{array}$ & & & & & & & \\
\hline
\end{tabular}


Fig.1 Iron and zinc content in brown and white rice
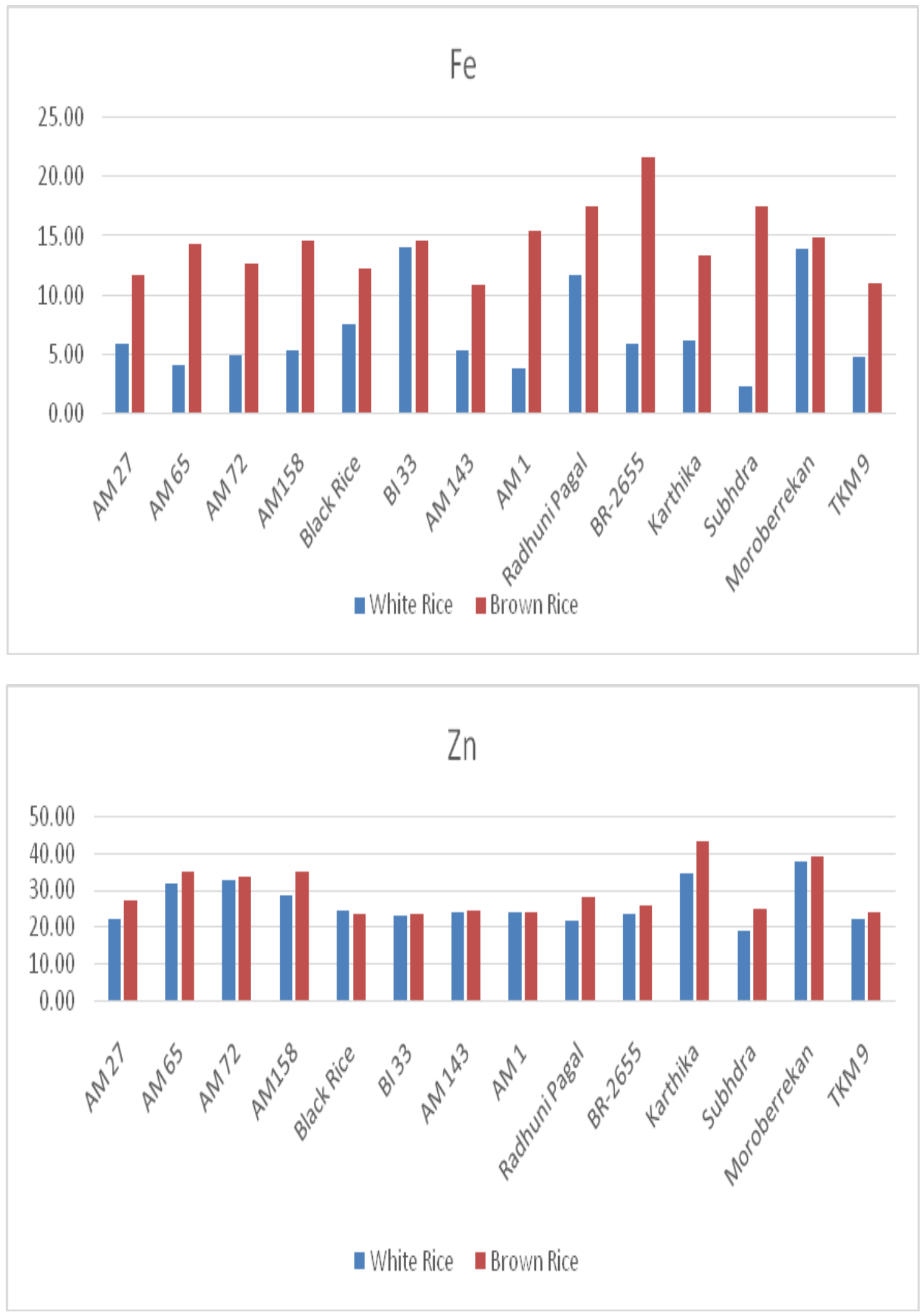
Fig.2 Volume expansion of white rice for different varieties after cooking
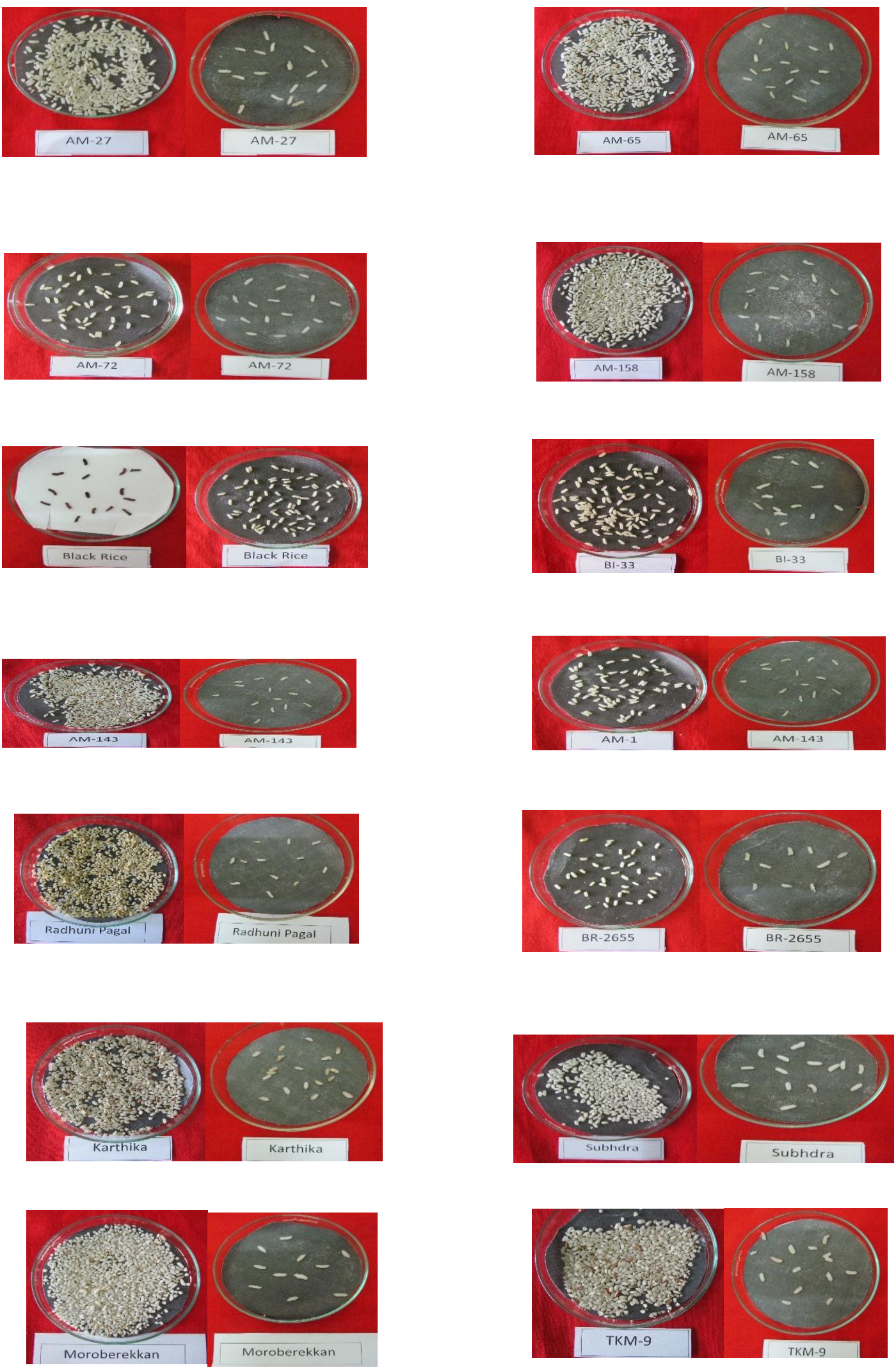
Evaluation of genotypes for Zinc and Iron content in different parts of rice grain

\section{Zinc and Iron content in brown, white and cooked rice}

Zinc and Iron content in different parts of rice grain i.e., brown rice (after removing husk), white rice (obtained after polishing of brown rice) and cooked rice (obtained after cooking of white rice) of elite genotypes was estimated using XRF at ICRISAT, Hyderabad and MSSRF, Chennai (Table 2).

Highest grain Zinc content in brown rice was observed in Karthika (43.00 mg kg-1), lowest in Black rice $\left(23.35 \mathrm{mg} \mathrm{kg}^{-1}\right)$. Highest zinc content in white rice was observed in Moroberekkan $\left(37.45 \mathrm{mg} \mathrm{kg}^{-1}\right)$ and lowest in Subhdra $\left(18.70 \mathrm{mg} \mathrm{kg}^{-1}\right)$. Highest zinc content in cooked rice was observed in Moroberekkan (33.50 mg kg $\left.{ }^{-1}\right)$ and lowest in Subhdra (15.45 $\left.\mathrm{mg} \mathrm{kg}^{-1}\right)$.

Highest iron content in brown rice was observed in BR-2655 (21.70 mg kg-1), lowest in AM-143 (10.90 mg kg $\left.{ }^{-1}\right)$. Highest iron content in White rice was found in BI-33 (14.05 mg kg-1) and lowest in Subhdra (2.20 $\left.\mathrm{mg} \mathrm{kg}^{-1}\right)$. Highest iron content in cooked rice was recorded in Radhunipagal $\left(31.10 \mathrm{mg} \mathrm{kg}^{-}\right.$ ${ }^{1}$ ) and lowest in Subhdra (6.85 $\mathrm{mg} \mathrm{kg}^{-1}$ ) ((Figure 1).

The range in the means of $\mathrm{Zn}$ and Fe content in brown rice, $\mathrm{Zn}$ content in brown rice, $\mathrm{Zn}$ and Fe content in white rice is higher except for $\mathrm{Fe}$ content in brown rice, but there were no reports on these traits earlier. Tiwari et al., (2009) reported grain zinc content in wheat mapping population, ranged from 19.9 to 64.2 $\mathrm{mg} / \mathrm{kg}$. Similarly, Grain zinc content ranged from 0.4 to $104 \mathrm{mg} / \mathrm{kg}$ in rice germplasm accessions (Anuradha et al., 2012) and Bekele et al., (2013) reported 16.1 to $88.6 \mathrm{mg} / \mathrm{kg}$ for the RIL population in rice.

\section{Evaluation of elite genotypes for cooking characters}

The mean sum of squares due to various sources of variation for different characters of fourteen genotypes is represented in table 3 . Highly significant differences among the genotypes were observed for all the characters indicating variability for the cooking associated traits. Volume expansion of white rice for different varieties after cooking is shown in figure 2.

For cooking characters significant differences among genotypes were observed. For water uptake before and after cooking Ahmed and Khalid (1985) reported the significant differences among genotypes. For elongation ratio Singh et al., (2000) reported the variations and results in present study are in accordance to that.

Analysis of variance revealed significant mean sum of squares for all the characters studied indicating the presence of variability among the genotypes. Thus, it could be concluded that there exists a lot of genetic variation among the genotypes and improvement could be brought through simple selection. On the basis of mean performance of genotypes for different characters, the varieties namely, Moroberekkan, BR-2655 and AM-1 showed best performance in terms of grain yield as well as their iron and zinc content. Thus, the above mentioned varieties can be recommended to be grown in order to solve the problem of hidden hunger i.e. malnutrition in the region.

\section{References}

Ahmed, M. and Z. M. Khalid, 1985, Some studies on the grain quality characteristics of rice. Sarhad J. Agric., 1(1): 123-128. 
Anuradha, K., Agarwal, S., Rao, V., V. Y., Rao, K. V., Viraktamath, B. C. and Sarla, N., 2012, Mapping QTLs and candidate genes for iron and zinc concentrations in unpolished rice of Madhukar×Swarna RILs. Gene, 508: 233-240.

Baishya, L., Sarkar, D., Ansari, M. and Prakash, N., 2015, Yield, quality and profitability of rice (Oryza sativa L.) varieties grown in the eastern Himalayan region of India. Afr. J. Agric. Res., 10(11):1177-1183.

Banerjee, S. and Chandel, G., 2011, Understanding the role of metal homeostasis related candidate genes in $\mathrm{Fe} / \mathrm{Zn}$ uptake, transport and redistribution in rice using semiquantitative RT-PCR. J. Pl. Mol. Biol. Biotechnol., 2 (1): 33-46.

Bekele, B. D., Naveen, G. K., Rakhi, S. and Shashidhar, H. E., 2013, Genetic evaluation of recombinant inbred lines of rice (Oryza sativa L.) for grain zinc concentrations, yield related traits and identification of associated SSR markers. Pak. J. Biol. Sci., 16(23):17141721.

Dhananjaya, M. V., Rudraradhya, M., Kulkarni, R. S. and Bhushan, H. O., 1998, Variability and character association in elite lines of rice (Oryza sativa L.). Curr. Res., 27 (9-10): 166168.

Gande, N., Kundur, P., Soman, R., Ambati, R., Ashwathanarayana, R., Bekele, B. and Shashidhar, H.E., 2014, Identification of putative candidate gene markers for grain zinc content using recombinant inbred lines (RIL) population of IRRI38 X Jeerigesanna. Afr. J. Biotechnol., 13(5):657-663.

Hemareddy, H. B., 1993, Studies on genetic variability, correlations, path coefficient analysis and selection indices in the hill zone rice (Oryza sativa L.) germplasm of Karnataka. M. Sc. (Agri) thesis, Univ. Agric. Sci., Bangalore, India.

Lu, L., Tian, S., Lia, S., Zhang, J., Yang, X., Labavitch, J, M. and Chen, W., 2013, Analysis of Metal Element Distributions in Rice (Oryza sativa L.) Seeds and Relocation during Germination Based on X-Ray Fluorescence Imaging of Zn, Fe, K, Ca, and Mn. PLoS ONE, 8(2): 57360.

Nagabhushana, K., 2002, Detection of main effect QTL controlling plant traits and identification and mapping of RAPD markers associated with plant height in Rice (Oryza sativa L.). M. Sc. (Agri) thesis, Univ. Agric. Sci., Bangalore.

Nicholas, G. P., Lachlan, J.P., Paul, J. M., Georgia, E.G., James, C.R.S., 2012, Energy - dispersive X-ray fluorescence analysis of zinc and iron concentration in rice and pearl millet grain. Pl. soil, 361:251-260.

Singh, R. K., Singh U.S. and Khush, G.S., 2000, Rice grain quality evaluation procedures.1: pp15-27.Oxford \& IBH publishing Co. Pvt. Ltd., New Delhi.

Venkataramana, P. and Hittalmani, S., 1999, Genetic variability on some important traits in two F2segregants of rice (Oryza sativa L.). Crop Res., 18 (1): 53-56.

\section{How to cite this article:}

Saurabh Pandey, D. Dayal Doss and Shashidhar, H.E. 2018. Evaluation of Elite Accessions of Rice for Morphological and Nutritional Traits. Int.J.Curr.Microbiol.App.Sci. 7(02): 3572-3580. doi: https://doi.org/10.20546/ijcmas.2018.702.424 